\title{
STUDY OF EFFECT OF MOUTHPIECE AND BMI ON AUDITORY AND VISUAL REACTION TIME AMONG UNDERGRADUATE MEDICAL STUDENTS: A COMPARATIVE STUDY
}

\author{
Sanjay S. Pandarbale1, S. R. Sardessai², Nitin Y. Dhupdale3, Narayan V. Kamat Dalal', J. R. Pednekar ${ }^{5}$ \\ ${ }^{1}$ Associate Professor, Department of Physiology, Goa Medical College, Bambolim, Goa. \\ 2 Professor, Department of Physiology, Goa Medical College, Bambolim, Goa. \\ ${ }^{3}$ Lecturer, Department of Preventive and Social Medicine, Goa Medical College, Bambolim, Goa. \\ ${ }^{4}$ Assistant Lecturer, Department of Physiology, Goa Medical College, Bambolim, Goa. \\ 5Professor, Department of Physiology, Pandit Deendayal Upadhyay Dental College, Kegaon, Solapur.
}

ABSTRACT

\section{BACKGROUND}

Published literature in exercise physiology has suggested that use of mouthpiece leads to performance improvement. It is attributed to the appropriate positioning of temporomandibular joint (TMJ) which improves blood circulation in the region surrounding TMJ. Mouthpiece will help in achieving required positioning of TMJ. Mouthpiece is often used during sports performance as a protective device. In the event that the mouthpiece could also provide additional benefit of improving performance, it will prove to be a great boon to the users.

The aim of this study was to find out the effect of mouthpiece and BMI on auditory and visual reaction time.

\section{MATERIALS AND METHODS}

A total of 140 healthy medical students participated in the study, which comprised of 50 males and 90 females. An electric bulb was used to generate visual stimulus while a switch was used to generate auditory stimulus.

\section{RESULTS}

Visual Reaction Time (VRT) was reduced among mouthpiece using females with normal weight as compared to non-users $(\mathrm{p}<0.01)$. VRT was seen to be reduced in underweight females using mouthpiece as compared to non-users $(\mathrm{p}<0.001)$. Auditory Reaction Time (ART) was seen to be reduced among overweight females using mouthpiece $(\mathrm{p}<0.05)$. Among males using mouthpiece, the ART and VRT was observed to be reduced across all the BMI categories; however, it was not statistically significant.

\section{CONCLUSION}

Use of mouthpiece improves both auditory and visual reaction time.

\section{KEYWORDS}

BMI (Body Mass Index), ART (Auditory Reaction Time), VRT (Visual Reaction Time), Mouthpiece.

HOW TO CITE THIS ARTICLE: Pandarbale SS, Sardessai SR, Dhupdale NY, et al. Study of effect of mouthpiece and BMI on auditory and visual reaction time among undergraduate medical students: A comparative study. J. Evolution Med. Dent. Sci. 2017;6(2):100102, DOI: $10.14260 / \mathrm{Jemds} / 2017 / 25$

\section{BACKGROUND \\ In day-to-day life all people are compelled to respond to certain urgent situations instantaneously, for example, car driving, answering mobile call ${ }^{1}$ or crossing a road, or catching a local train, all these require a fast reaction time. Reaction time is the period that occurs between a stimulus and the initiation of muscle response. ${ }^{2}$ It is one of the easiest and quickest measure of studying information processing ability of Central Nervous System (CNS) and person's ability to concentrate and coordinate. In the existing literature, it is documented in the previous studies that mouthpiece has protective as well as performance enhancing ability of the individual. ${ }^{3}$ The neurophysiological studies suggest that a relationship exists between cognition, attention, memory and BMI. 4}

Financial or Other, Competing Interest: None.

Submission 26-11-2016, Peer Review 24-12-2016,

Acceptance 30-12-2016, Published 05-01-2017.

Corresponding Author:

Dr. Sanjay S. Pandarbale,

Associate Professor,

Department of Physiology,

Goa Medical College,

Bambolim-403202, Goa.

E-mail: drsanjayspandarbale@gmail.com

DOI: $10.14260 /$ jemds $/ 2017 / 25$

\section{MATERIALS AND METHODS}

A total of 140 apparently healthy medical students aged between 18-20 years were selected as subjects ( 50 boys and 90 girls). These students were selected after explaining the purpose of the study and written informed consent was obtained.

The study participants were included in the study by applying inclusion criteria of willingness to participate and readiness to give consent. They were screened for any prior history of consuming any sedatives, anti-histaminic, alcohol, regular exercise, martial arts, pranayama, yoga or meditation which are exclusion criteria.

Subjects' height and weight were taken and BMI was calculated by using the formula weight in $\mathrm{kg} /$ height in $\mathrm{m}^{2}$. The students were categorised as underweight $(<18.5$ $\left.\mathrm{kg} / \mathrm{m}^{2}\right)$, normal or lean BMI $\left(18.5-22.9 \mathrm{~kg} / \mathrm{m}^{2}\right)$, overweight $\left(23.0-24.9 \mathrm{~kg} / \mathrm{m}^{2}\right)$ and obese $\left(\geq 25 \mathrm{~kg} / \mathrm{m}^{2}\right)$ based on the revised consensus guidelines for India. ${ }^{5}$ The visual and auditory reaction time (Fig A \& B) was measured by asking the subject to open a key kept in series with an electromagnetic time marker as quickly as he/she could do with the dominant hand after noticing a light or sound stimulus initially without mouthpiece and subsequently using mouthpiece. For the purpose of recording VRT with eyes opened, stimulus used was an electric bulb. The ART and VRT were calculated by measuring the distance between the point 
of application of stimulus and the response of the subject were automatically recorded on a moving drum.

The ART was recorded by using two keys and electromagnetic event marker to a set of batteries in series (Figure A \& B). "O" is the observer's key (Sound of switch acts as auditory stimulus) and ' $S$ ' is the subject's key. Kymograph with speed of $640 \mathrm{~mm} / \mathrm{sec}$ was used to record stimulus. Each subject sat in a relaxed position with eyes closed and held the hand switch with a dominant hand, with the hand in position to press the button to break the circuit.

Students were allowed to undergo practice trials till they were able to perform the task as required of them. The shortest VRT and ART were accepted among three trials. The reaction time for light as well as sound were measured for each subject.6,7 All data were expressed as mean \pm SEM. Student $t$ test was used for statistical analysis and $P$ value of $<0.05$ was considered as statistically significant.

Sample size was calculated by using purposive sampling technique.

\section{RESULTS}

\begin{tabular}{|c|c|c|c|c|}
\hline \multirow[b]{2}{*}{ BMI } & \multicolumn{2}{|c|}{ ART (sec) } & \multicolumn{2}{|c|}{ VRT (sec) } \\
\hline & $\begin{array}{l}\text { Without } \\
\text { Mouth } \\
\text { Piece }\end{array}$ & $\begin{array}{c}\text { With } \\
\text { Mouth } \\
\text { Piece }\end{array}$ & $\begin{array}{c}\text { Without } \\
\text { Mouth } \\
\text { Piece }\end{array}$ & $\begin{array}{c}\text { With } \\
\text { Mouth } \\
\text { Piece }\end{array}$ \\
\hline $\begin{array}{l}\text { Normal } \\
\text { Weight } \\
(n=47)\end{array}$ & & & & \\
\hline Mean & 0.19 & 0.18 & 0.19 & 0.18 \\
\hline SD & 0.038 & 0.037 & 0.043 & 0.036 \\
\hline SEM & 0.0054 & 0.0051 & 0.0054 & 0.0049 \\
\hline t value & 2.7 & & 2.77 & \\
\hline P value & $<0.01^{*}$ & & $<0.01^{*}$ & \\
\hline $\begin{array}{l}\text { Underweight } \\
(\mathrm{n}=26)\end{array}$ & & & & \\
\hline Mean & 0.184 & 0.185 & 0.19 & 0.17 \\
\hline SD & 0.031 & 0.048 & 0.039 & 0.042 \\
\hline SEM & 0.0058 & 0.009 & 0.007 & 0.008 \\
\hline t value & 0.1 & & 1.859 & \\
\hline P value & $<0.09$ & & $<0.001^{*}$ & \\
\hline $\begin{array}{c}\text { Overweight and } \\
\text { Above } \\
(\mathrm{n}=17)\end{array}$ & & & & \\
\hline Mean & 0.181 & 0.184 & 0.191 & 0.16 \\
\hline SD & 0.037 & 0.052 & 0.0303 & 0.045 \\
\hline SEM & 0.009 & 0.013 & 0.0072 & 0.011 \\
\hline t value & 0.19447 & & 2.39 & \\
\hline P value & $<0.09$ & & $<0.05$ & \\
\hline $\begin{array}{c}\text { Tal } \\
B N\end{array}$ & $\begin{array}{l}\text { Effect } \\
\text { ART ar }\end{array}$ & $\begin{array}{l}\text { Mouth } \\
\text { RT in }\end{array}$ & $\begin{array}{l}\text { e and } \\
\text { nales }\end{array}$ & \\
\hline
\end{tabular}

\begin{tabular}{|c|c|c|c|c|}
\hline Parameters & ART (sec) & & VRT (sec) & \\
\hline & $\begin{array}{l}\text { Without } \\
\text { Mouth } \\
\text { Piece }\end{array}$ & $\begin{array}{c}\text { With } \\
\text { Mouth } \\
\text { Piece }\end{array}$ & $\begin{array}{c}\text { Without } \\
\text { Mouth } \\
\text { Piece }\end{array}$ & $\begin{array}{c}\text { With } \\
\text { Mouth } \\
\text { Piece }\end{array}$ \\
\hline \multicolumn{5}{|l|}{$\begin{array}{c}\text { Normal } \\
\text { Weight }(n=25)\end{array}$} \\
\hline Mean & 0.18 & 0.16 & 0.195 & 0.181 \\
\hline SD & 0.039 & 0.026 & 0.034 & 0.041 \\
\hline SEM & 0.008 & 0.005 & 0.007 & 0.008 \\
\hline
\end{tabular}

\begin{tabular}{|c|c|c|c|c|}
\hline t value & 2.05 & & 0.91 & \\
\hline $\mathrm{P}$ value & $<0.1$ & & $<0.4$ & \\
\hline \multicolumn{5}{|c|}{$\begin{array}{l}\text { Underweight } \\
(n=4)\end{array}$} \\
\hline Mean & 0.17 & 0.13 & 0.21 & 0.18 \\
\hline SD & 0.052 & 0.021 & 0.022 & 0.059 \\
\hline SEM & 0.026 & 0.010 & 0.011 & 0.029 \\
\hline t value & 1.43 & & 0.96 & \\
\hline P value & $<0.3$ & & $<0.4$ & \\
\hline \multicolumn{5}{|c|}{$\begin{array}{l}\text { Overweight } \\
(\mathrm{n}=21)\end{array}$} \\
\hline Mean & 0.18 & 0.17 & 0.20 & 0.17 \\
\hline SD & 0.036 & 0.029 & 0.036 & 0.033 \\
\hline SEM & 0.008 & 0.006 & 0.008 & 0.007 \\
\hline t value & 0.94 & & 0.87 & \\
\hline P value & $<0.4$ & & $<0.1$ & \\
\hline \multicolumn{5}{|c|}{$\begin{array}{l}\text { Table 2. Effect of Mouthpiece and } \\
\text { BMI on ART and VRT in Males }\end{array}$} \\
\hline
\end{tabular}

The results show that the mean height in females was $1.54 \mathrm{~m}$, mean weight was $49.68 \mathrm{~kg}$. Among males mean height was $1.69 \mathrm{~m}$ and mean weight was $59.2 \mathrm{~kg}$. In females with normal weight the ART and VRT have reduced among the mouthpiece users as compared to non-users $(\mathrm{p}<0.01)$ [Table 1]. In underweight females, VRT was found to reduce among the mouthpiece uses as compared to non-users $(p<0.001)$ [Table 1]. In overweight females, VRT was seen less among the mouthpiece users as compared to Non-users $(\mathrm{p}<0.05)$ [Table 1].

Among the males, ART and VRT was reduced among the mouthpiece users as compared to non-users; however, this difference was statistically significant $(\mathrm{P}<0.1)$ and $(\mathrm{p}<0.4)$ respectively [Table 2]. Similar findings were observed for the underweight and overweight males [Table 2].

Auditory reaction time in girls showed a significant improvement with a use of a mouthpiece vs. without a mouthpiece (Table 1) in normal weight girls $(\mathrm{p}<0.01)$. Visual reaction time in girls showed that participants performed slightly better with the mouthpiece vs. without the mouthpiece (Table 1) for underweight girls $(p<0.01)$. Overweight girls showed increase in ART and VRT (Table1).

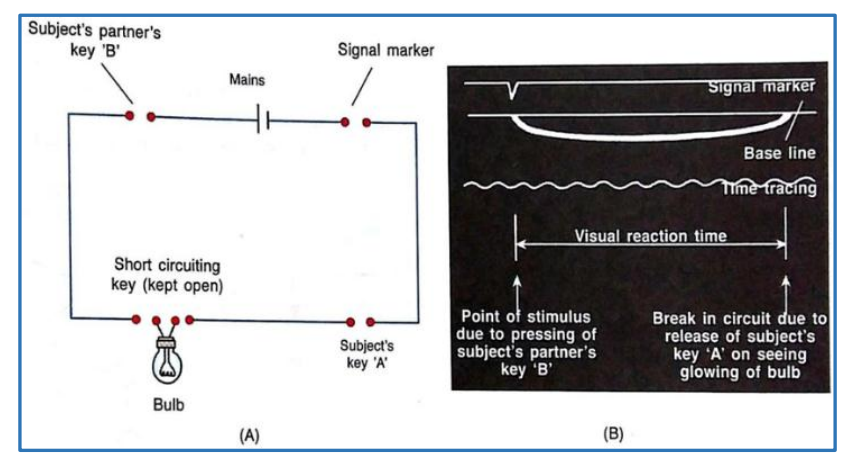

Figure 1. Diagram showing the Circuit for Visual Reaction Time and Measurement of Visual Reaction Time. ${ }^{2}$

\section{DISCUSSION}

Findings of present study show that auditory reaction time and visual reaction time decreased comparatively for both males and females among the mouthpiece users. In our study, the mean ART was seen to improve with the study 
participants using mouthpiece (160 ms) vs. those without mouthpiece (189 ms) and VRT was also seen to improve with mouthpiece (169 ms) vs. without mouthpiece (198 ms). In a similar study by Garner DP et al, 8 the mean ART was significantly improved with mouthpiece use (241.44 ms) vs. without mouthpiece use $(249.94 \mathrm{~ms})$. It has been documented that clenching of the jaw triggers release of cortisol hormones. Sports mouthpieces prevent teeth clenching and relieves pressure on the TMJ. By preventing the excessive production of hormones, the body is able to work to its full potential. These improvements may be due to an enhancement in temporomandibular joint (TMJ) positioning. ${ }^{8}$

Studies in the past suggest that by positioning TMJ appropriately leads to improved circulation of blood flow and oxygenation in the region of TMJ and CNS. Improper positioning of TMJ occludes nerves and arteries of the joint causing strain to neighbouring tissues, thus compromising blood flow to TMJ. ${ }^{8}$

The most accepted explanation of prolonged VRT as compared to ART is involvement of certain chemical changes. $^{9-11}$ In addition, collateral signal transmission pathways is another factor contributing to delay perception of visual stimulus, ${ }^{12}$ the inherent difference in the kind of receptor involved at the level of eye (retina) and ear (organ of corti) and their stimulation.

Auditory reaction time is associated with efficient spiral organ receptors in the middle ear, which transfer sound to the temporal lobes of cerebral cortex via sensory neurons.8,13

There was improvement in ART and VRT in underweight males with or without use of mouthpiece, while there was improvement in VRT in underweight girls with or without use of mouthpiece and decrease in ART without use of mouthpiece. ${ }^{13}$ BMI affected the ART, which was an indirect measure of the sensory motor association. ${ }^{14}$ Females had higher BMI and longer reaction time than males. There was significant positive correlation between BMI and reaction time in both males and females. Females had higher BMI and longer reaction time than males.

There was significant positive association between BMI and VRT and ART in both males and females. Longer reaction time and higher BMI in females could be attributed to fluid and salt retention due to female sex hormones affecting sensorimotor coordination. ${ }^{15,16}$

\section{CONCLUSION}

The use of mouthpiece improves both auditory and visual reaction time. Many major athletic events engage the use of auditory and visual signals and the improved reaction time to help in achieving desirable performance of the sports personnel. Hence, athletes may be able to derive additional benefits in improving their performance by using a mouthpiece.

\section{Recommendation}

It is recommended that mouthpiece could be used as a routine protective as well as performance aid in all the sporting events, as well to all the professionals where the quick reaction time is a matter of concern.

\section{Limitations}

The Sample size used in the present study was small which led to statistically not significant results and therefore studies with larger sample would produce statistically significant results.

\section{REFERENCES}

[1] Shah C, Gokhale PA, Mehta H. Effect of mobile use on reaction time. J Med 2010;3:160-4.

[2] Jain AK. Manual of Practical Physiology. $5^{\text {th }}$ edn. New Delhi: APC publishing company http://www.apcbooks.co.in/book/5393/manual-ofpractical-physiology-for-mbbs (2016).

[3] Alexander CF. A study on the effectiveness of a self-fit mandibular repositioning appliance on increasing human strength and endurance capabilities. University of Tennessee Trace tennessee. edu/cgi/viewcontent.cgi?article=1747\&context=utk_g radthes (1999).

[4] Borker AS, Pednekar JR. Effect of pranayam on visual and auditory reaction time. Indian J Physiol Pharmacol 2003;47(2):229-30.

[5] Aziz N, Kallur SD, Nirmalan PK. Implications of the revised consensus body mass indices for Asian Indians on clinical obstetric practice. J Clin Diagnostic Res 2014;8(5):0C01-3.

[6] Mohan M, Thombre DP, Das AK, et al. Reaction time in clinical diabetes mellitus. Indian J Physiol Pharmacol 1984;28(4):311-4.

[7] Bourdin M, Brunet-Patru I, Hager PE, et al. Influence of maxillary mouthguards on physiological parameters. Med Sci Sports Exerc 2006;38(8):1500-4.

[8] Garner DP, Miskimin J. Effects of mouthpiece use on auditory and visual reaction time in college males and females. Compend Contin Educ Dent 2009;30 Spec No 2:14-7.

[9] Ganong W. Review of medical physiology. 22nd edn. Singapore: McGraw Hill, 2005.

[10] Guyton AC, Hall JE. Textbook of Medical Physiology. Elsevier Saunders 2006.

[11] Lofthus GK. Sensorimotor performance and limb preference. Percept Mot Skills 1981;52(3):683-93.

[12] Rapisura KP, Coburn JW, Brown LE, et al. Physiological variables and mouthguard use in women during exercise. J Strength Cond Res 2010;24(5):1263-8.

[13] Misra N, Mahajan KK, Maini BK. Comparative study of visual and auditory reaction time of hands and feet in males and females. Indian J Physiol Pharmacol 1985;29(4):213-8.

[14] Nikam LH, Gadkari JV. Effect of age, gender and body mass index on visual and auditory reaction times in Indian population. Indian J Physiol Pharmacol 2012;56(1):94-9.

[15] Jadhao P, Kamble P, Deshpande VK, et al. The study of auditory and visual reaction times in chronic smokers. Int J Med Heal Sci 2013;2(1):275-81.

[16] Deore DN, Surwase SP, Masroor S, et al. A cross sectional study on the relationship between the body mass index (BMI) and the audiovisual reaction time (ART). J Clin Diagn Res 2012;6(9):1466-8. 